\section{Eschatology in oncology: life expectancy of untreated patients with malignant tumors}

https://doi.org/10.37336/2707-0700-2020-3-5

\author{
N.N. Kolotilov \\ SI "Institute of Nuclear Medicine \\ and Diagnostic Radiology of the National \\ Academy of Medical Sciences \\ of Ukraine", Kiev, Ukraine
}

Two millennia before the invention of the microscope, cancer diagnosis was a combination of careful observation and hypothesis. However, Hippocrates clearly had good reason to identify a group of certain conditions as cancerous tumors and wrote about their treatment the following: "In cases of latent cancer, it is better not to resort to any treatment, since the treated patients die quickly, and without treatment they can live a long time" (Hippocrates, Aphorism \# 38).

Relevance of the topic. Despite all the theoretical prerequisites for a new breakthrough in oncology, the absolute gain from the introduction of anticancer drugs does not significantly increase over the years: the increase in the median survival rate, as well as in the era of empirical chemotherapy, is measured in weeks and months [1]. In most cases, the new treatment can significantly extend the life of some patients, despite the fact that the average gain is measured in several months or even days.

Knowledge of the clinical prognosis of untreated cancer of any localization is useful in patients with advanced disease or in conditions of underdeveloped healthcare system [9].

Historical data on untreated breast cancer patients in some cases demonstrate the possibility of long-term survival. The spectrum of breast cancer clinical aggressiveness varies with virulence and chronic disease.

Although some cancers are invariably fatal, others are latent and do not affect the patient's life expectancy [8].

File of the article [16] (The University of Texas, MD Anderson Hospital and Tumor Institute at Houston, Texas Medical Center, Houston, Texas, USA), published in 1973, can now be downloaded for $\$ 35.95$, that certainly illustrates the relevance of the topic. In modern domestic literature, such materials are practically absent; in the English language we will limit ourselves by mentioning the works $[5-9,11,14,16,17]$. We can only mention the monograph [3], which contains the data [12], that stimulated the creation of this article.

The purpose of the article is to remind about the problem of studying the natural life expectancy of patients with untreated cancer.

Walter Sydney Lazarus-Barlow (18.06.186515.01.1950) - English physician, professor of experimental pathology at London Middlesex Hospital (1745-2005). Oncologist and one of the first radiologists who investigated the effects of $\mathrm{X}$-rays and radium on cancer. The author of one of the first studies of the natural life expectancy of untreated patients with cancers of various localization [12]: the records of the Middlesex hospital were analyzed for a period of 40 years (1883-1922). Its results cover 2556 unoperated patients with cancerous tumors of 29 localizations (Table 1).

The average life expectancy was calculated for the ten-year age periods in all cases, but in table 2 only those figures are given that are obtained on the basis of a reasonable number of observations (table 2). The research methodology was well thought out, and statistics was used adequately. It is noted that similar indicators are being developed by the Cancer Christy Hospital in Manchester and the Royal Glasgow Cancer Hospital.

Breast cancer. 250 patients were observed for 12 years to death (Division of Radiation Oncology, University of California, San Diego, California, Division of Medical Oncology, Department of Clinical Research, Naval Medical Center San Diego, San Diego, California). The median survival time was 2.7 years. The actuarial 5 - and 10 -year survival rates for these patients with untreated breast cancer were $18.4 \%$ and $3.6 \%$, respectively [9].

An observation [16] of a patient with breast cancer who refused the treatment for 20 years is described. The tumor showed absolutely no pro- 
Table 1.

Natural life expectancy (months) of patients with cancerous tumors of various localization [12].

\begin{tabular}{|c|c|c|c|c|c|}
\hline \multirow{2}{*}{ Localization } & \multirow{2}{*}{ Gender } & \multirow{2}{*}{$\mathbf{n}$} & \multicolumn{3}{|c|}{ Life expectancy } \\
\hline & & & $\min$ & average & $\max$ \\
\hline Thyroid & $\mathrm{m}+\mathrm{f}$ & $3+2$ & 3 & 8,6 & 13 \\
\hline Neck & $\mathrm{m}$ & 36 & 3 & 9,4 & 37 \\
\hline$-/ /-$ & $\mathrm{f}$ & 7 & 6 & 12,0 & 31 \\
\hline Liver and gallbladder & $\mathrm{m}$ & 7 & 7 & 13,0 & 26 \\
\hline$-/ /-$ & $\mathrm{f}$ & 23 & 2 & 10,8 & 44 \\
\hline Pancreas & $\mathrm{m}+\mathrm{f}$ & $5+8$ & 3 & 11,2 & 36 \\
\hline Pharynx & $\mathrm{m}$ & 32 & 3 & 11,8 & 26 \\
\hline$-/ /-$ & $\mathrm{f}$ & 6 & 7 & 15,8 & 34 \\
\hline Esophagus & $\mathrm{m}$ & 63 & 2 & 12,1 & 51 \\
\hline$-/ /-$ & $\mathrm{f}$ & 11 & 2 & 19,4 & 56 \\
\hline Cheeks & $\mathrm{m}$ & 29 & 3 & 13,4 & 27 \\
\hline$-/ /-$ & $\mathrm{f}$ & 7 & 6 & 12,0 & 31 \\
\hline Larynx & $\mathrm{m}$ & 44 & 3 & 14,0 & 40 \\
\hline$-/ /-$ & $\mathrm{f}$ & 11 & 4 & 14,0 & 37 \\
\hline Muscles (sarcomas) & $m+f$ & $2+1$ & 8 & 14,0 & 38 \\
\hline Long bones & $m+f$ & $10+5$ & 2 & 14,1 & 27 \\
\hline Tonsils & $m+f$ & $23+2$ & 3 & 14,2 & 42 \\
\hline Parotid gland & $m+f$ & $1+3$ & 11 & 14,5 & 19 \\
\hline Kidney & $m+f$ & $8+9$ & 3 & 15,1 & 51 \\
\hline Ovaries & $\mathrm{f}$ & 22 & 3 & 15,1 & 38 \\
\hline Bladder & $\mathrm{m}$ & 22 & 2 & 26,9 & 101 \\
\hline$-/ /-$ & $\mathrm{f}$ & 18 & 4 & 15,2 & 44 \\
\hline Prostate & $\mathrm{m}$ & 17 & 6 & 15,4 & 46 \\
\hline Tongue and oral cavity & $\mathrm{m}$ & 225 & 3 & 15,9 & 75 \\
\hline$-/ /-$ & $f$ & 18 & 6 & 17,4 & 37 \\
\hline Colon & $\mathrm{m}$ & 32 & 2 & 16,0 & 51 \\
\hline$-/ /-$ & $\mathrm{f}$ & 45 & 2 & 19,2 & 98 \\
\hline Stomach & $\mathrm{m}$ & 61 & 3 & 16,5 & 60 \\
\hline$-/ /-$ & $f$ & 58 & 3 & 17,2 & 50 \\
\hline Underlip & $\mathrm{m}$ & 19 & 7 & 18,3 & 42 \\
\hline Peritoneum & $m+f$ & $1+7$ & 4 & 19,4 & 53 \\
\hline Rectum & $\mathrm{m}$ & 172 & 3 & 20,4 & 86 \\
\hline$-/ /-$ & $f$ & 173 & 3 & 25,9 & 122 \\
\hline Cervix & $\mathrm{f}$ & 916 & 3 & 21,3 & 126 \\
\hline Penis & $\mathrm{m}$ & 8 & 10 & 21,4 & 52 \\
\hline Vagina + vulva & $\mathrm{f}$ & 57 & 5 & 22,1 & 181 \\
\hline Short bones & $m+f$ & $33+20$ & 2 & 22,5 & 311 \\
\hline Scrotum & $\mathrm{m}$ & 3 & 15 & 23,0 & 29 \\
\hline Uterus body & $\mathrm{f}$ & 28 & 5 & 24,2 & 88 \\
\hline Breast & $\mathrm{f}$ & 243 & 2 & 38,4 & 210 \\
\hline
\end{tabular}


Table 2.

Natural life expectancy (months) of patients with cancer of 5 primary localizations, calculated by the age of the expected onset [12].

\begin{tabular}{|c|c|c|c|c|c|}
\hline \multirow{2}{*}{ Localization } & \multirow{2}{*}{ Age } & \multicolumn{3}{|c|}{ Life expectancy } & \multirow{2}{*}{$\begin{array}{l}\% \text { patients with } \\
\text { average life } \\
\text { expectancy }\end{array}$} \\
\hline & & $\min$ & $\max$ & average & \\
\hline \multicolumn{6}{|c|}{ Female } \\
\hline \multirow{6}{*}{ Breast } & $\begin{array}{l}25-34 \\
(n=15)\end{array}$ & 3 & 196 & 36,0 & 80,0 \\
\hline & $\begin{array}{l}35-44 \\
(n=42)\end{array}$ & 5 & 112 & 32,0 & 64,3 \\
\hline & $\begin{array}{l}45-54 \\
(n=61)\end{array}$ & 2 & 186 & 39,2 & 68,8 \\
\hline & $\begin{array}{l}55-64 \\
(n=60)\end{array}$ & 3 & 210 & 40,7 & 70,0 \\
\hline & $\begin{array}{l}65-74 \\
(n=44)\end{array}$ & 11 & 169 & 44,3 & 63,6 \\
\hline & $\begin{array}{c}>75 \\
(n=20)\end{array}$ & 12 & 64 & 36,1 & 50,0 \\
\hline \multirow{7}{*}{ Cervix } & $\begin{array}{l}<25 \\
(\mathrm{n}=3)\end{array}$ & 6 & 17 & 13,0 & 33,3 \\
\hline & $\begin{array}{l}25-34 \\
(n=96)\end{array}$ & 5 & 100 & 18,6 & 60,4 \\
\hline & $\begin{array}{c}35-44 \\
(\mathrm{n}=295)\end{array}$ & 3 & 126 & 21,4 & 66,1 \\
\hline & $\begin{array}{c}45-54 \\
(n=316)\end{array}$ & 3 & 120 & 21,4 & 66,1 \\
\hline & $\begin{array}{c}55-64 \\
(n=150)\end{array}$ & 6 & 130 & 22,4 & 62,7 \\
\hline & $\begin{array}{l}65-74 \\
(n=49)\end{array}$ & 4 & 223 & 24,9 & 69,4 \\
\hline & $\begin{array}{l}>75 \\
(n=7)\end{array}$ & 5 & 21 & 11,3 & 57,1 \\
\hline \multirow{6}{*}{ Colon } & $\begin{array}{l}25-34 \\
(n=14)\end{array}$ & 3 & 122 & 29,9 & 78,6 \\
\hline & $\begin{array}{l}35-44 \\
(n=19)\end{array}$ & 3 & 34 & 16,7 & 52,6 \\
\hline & $\begin{array}{l}45-54 \\
(n=47)\end{array}$ & 4 & 67 & 26,3 & 63,8 \\
\hline & $\begin{array}{l}55-64 \\
(n=62)\end{array}$ & 7 & 73 & 26,8 & 54,8 \\
\hline & $\begin{array}{l}65-74 \\
(n=22)\end{array}$ & 6 & 63 & 26,4 & 59,1 \\
\hline & $\begin{array}{l}>75 \\
(\mathrm{n}=8)\end{array}$ & 10 & 109 & 32,0 & 62,5 \\
\hline
\end{tabular}


Continuation of table 2

\begin{tabular}{|c|c|c|c|c|c|}
\hline \multicolumn{6}{|c|}{ Male } \\
\hline \multirow{6}{*}{$\begin{array}{c}\text { Tongue } \\
\text { and oral cavity }\end{array}$} & $\begin{array}{c}25-34 \\
(n=7)\end{array}$ & 3 & 16 & 9,1 & 42,9 \\
\hline & $\begin{array}{l}35-44 \\
(n=33)\end{array}$ & 4 & 52 & 15,8 & 63,6 \\
\hline & $\begin{array}{l}45-54 \\
(n=70)\end{array}$ & 3 & 54 & 16,9 & 61,4 \\
\hline & $\begin{array}{l}55-64 \\
(n=74)\end{array}$ & 4 & 75 & 15,8 & 68,9 \\
\hline & $\begin{array}{l}65-74 \\
(n=33)\end{array}$ & 3 & 60 & 15,5 & 69,7 \\
\hline & $\begin{array}{l}>75 \\
(\mathrm{n}=7)\end{array}$ & 3 & 37 & 16,3 & 57,1 \\
\hline \multirow{7}{*}{ Rectum } & $\begin{array}{c}<25 \\
(\mathrm{n}=3)\end{array}$ & 3 & 12 & 9,0 & 33,3 \\
\hline & $\begin{array}{l}25-34 \\
(\mathrm{n}=10)\end{array}$ & 4 & 35 & 14,5 & 60,0 \\
\hline & $\begin{array}{l}35-44 \\
(n=19)\end{array}$ & 6 & 69 & 22,6 & 68,4 \\
\hline & $\begin{array}{l}45-54 \\
(\mathrm{n}=39)\end{array}$ & 4 & 54 & 20,1 & 64,4 \\
\hline & $\begin{array}{l}55-64 \\
(\mathrm{n}=59)\end{array}$ & 4 & 86 & 21,2 & 67,8 \\
\hline & $\begin{array}{l}65-74 \\
(n=38)\end{array}$ & 4 & 56 & 25,2 & 68,4 \\
\hline & $\begin{array}{l}>75 \\
(\mathrm{n}=4)\end{array}$ & 6 & 38 & 24,0 & 50,0 \\
\hline
\end{tabular}

gression during this time, and the diagnosis was again confirmed when the patient agreed to removal. The literature was analyzed and several similar cases were found.

A study [17] enrolls 5339 patients $<80$ years of age with breast cancer registered in the Geneva Cancer Registry between 1975 and 2000. Patients who refused surgery were compared with those who agreed to surgery using logistic regression. The effect of surgery refusal on breast cancer mortality was assessed with Cox proportional hazards analysis. 70 women (1.3 $\%)$ refused surgery. These women were older, more often single, and had larger tumors. Overall, $37(53 \%)$ women received no treatment, $25(36 \%)$ - hormone therapy alone, and $8(11 \%)$ - other adjuvant treatments alone or in combination. The five-year specific breast cancer survival in women who refused surgery was lower than in those who agreed $(72 \%, 95$ $\%$ CI, 60-84 \% vs. $87 \%$, $95 \%$ CI, 86-88\%, respectively). After taking into account other prognostic factors, including tumor characteristics and stage, women who refused surgery had 2 times (95\% CI, 1.5-3.1) higher risk of death from breast cancer compared with those after surgery ( fig. 1).

Breast cancer patients with first metastasis to bones only tend to have a greater 5-year overall survival than patients with first metastasis to other tissues only [11]. Bone is the most common site for breast cancer metastasis. The biological mechanisms of bone metastasis may differ from those of non-bone metastases, and the identification of different signaling pathways and somatic mutations can provide an idea of the biology and adequate targets for the treatment and prevention of bone metastases. 


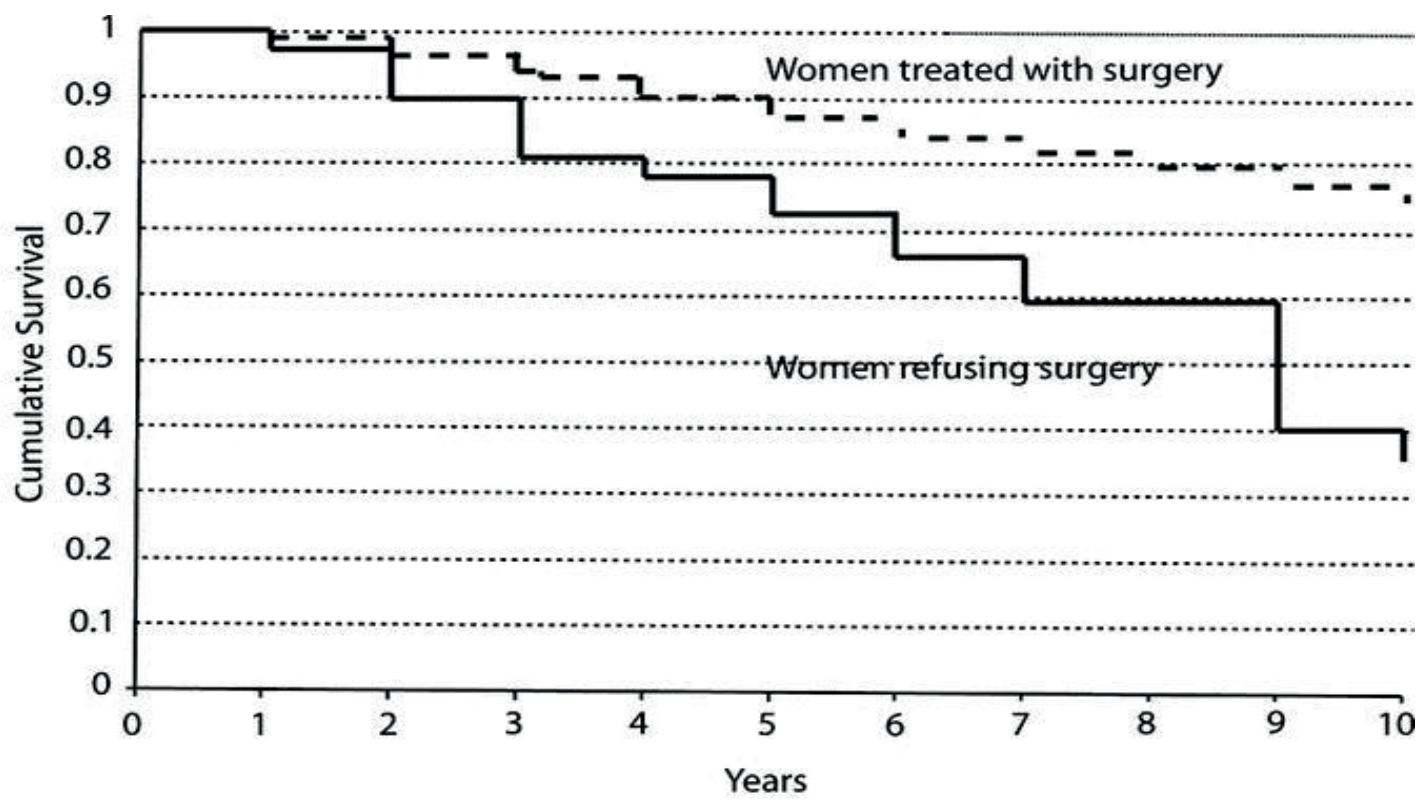

Number of women entering interval

\begin{tabular}{|c|c|c|c|c|c|c|c|c|c|c|}
\hline & \multicolumn{10}{|c|}{ Years } \\
\hline & 0 & 1 & 2 & 3 & 4 & 5 & 6 & 7 & 8 & 9 \\
\hline $\begin{array}{l}\text { Women treated } \\
\text { with surgery }(n)\end{array}$ & 5269 & 5117 & 4569 & 4065 & 3559 & 3155 & 2773 & 2463 & 2159 & 1880 \\
\hline $\begin{array}{l}\text { women refusing } \\
\text { surgery ( } n \text { ) }\end{array}$ & 70 & 66 & 57 & 49 & 41 & 35 & 30 & 24 & 20 & 11 \\
\hline
\end{tabular}

Fig. 1. Observed breast cancer-specific survival of breast cancer patients who chose not to undergo surgery and those who accepted surgery [17].

Hepatocellular carcinoma The histories of 627 untreated patients were analyzed (Table 3, Fig. 2) [6]. The overall median survival was 9 months. The main cause of the death was tumor progression $(\mathrm{n}=$ $279 ; 46.5 \%$ ). These data are necessary for investigation planning and patients' consultation.

Adenocarcinoma of the colon or rectum. The study [14] examined 583 cases of adenocarcinoma of the colon or rectum, in which no any treatment or palliative treatment alone (excluding radiation) were carried out. The median survival from the time of adenocarcinoma diagnosis to death was 9.8 months. Longer survival rates were observed in women, in patients with poorly differentiated tumors, and in cases of only localized adenocarcinoma spread. Shorter survival rates have been observed in patients with chronic ulcerative colitis.

Prostate cancer. Medical imaging technologies in overdiagnosis allow to detect prostate

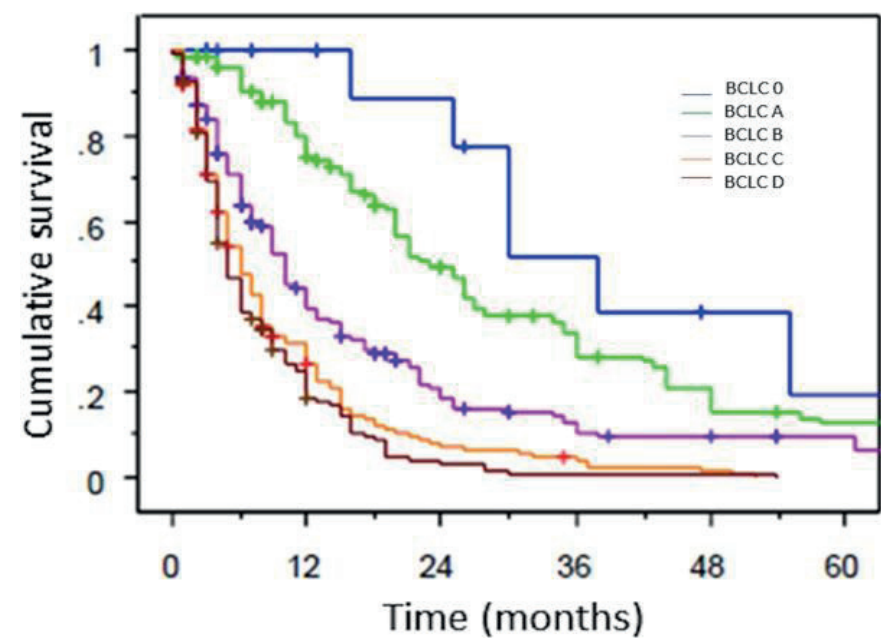

Fig. 2. Kaplan-Meier's curve showing the survival of the 600 patients with untreated hepatocellular carcinoma subdivided according to the BCLC stages (BCLC 0 , blue line; $B C L C A$, green line; $B C L C B$, purple line; $B C L C C$, orange line; $B C L C D$, red line) [6]. 
Table 3.

Dependence of the average survival on the stage of hepatocellular carcinoma according to the Barcelona Clinic Liver Cancer Classification [6].

\begin{tabular}{|c|c|c|}
\hline $\begin{array}{c}\text { Barcelona Clinic Liver } \\
\text { Cancer Classification }\end{array}$ & Semantics & Average survival \\
\hline stage 0 & Asymptomatic tumor $<2 \mathrm{~cm}$ in diameter & 38 months \\
\hline stage A & $\begin{array}{c}\text { Asymptomatic cancer }>2 \mathrm{~cm} \text { or multifocal cancer, } \\
\text { up to 3 lesions }<3 \mathrm{~cm} \text { in diameter }\end{array}$ & 25 months \\
\hline stage B & Asymptomatic multifocal tumor with metastases & 10 months \\
\hline stage C & Symptomatic multifocal tumor with metastases & 7 months \\
\hline stage D & Terminal stage & 6 months \\
\hline
\end{tabular}

cancer, which has no clinical manifestations and does not lead to fetal outcome.

The term "overdiagnosis" is now increasingly applied in the medical literature to indicate a side effect of technological progress. This term (should not be confused with false positive test results; in our presentation, overdiagnosis can only be referred to histologically verified cases) is used in the case of diagnosis a disease, the course of which will not lead to clinical manifestations or patient death [18].

The concept of "non-progressive" tumors (histologically verified tumors that do not grow or even regress) have something in common with overdiagnosis. Although the concept of non-progressive cancer may seem implausible, biological mechanisms for arresting cancer progression are already known $[13,15]$. Cancer overdiagnosis can be ascertained in a particular patient if he (she) never sought medical help for cancer and later died from other causes. Doctors do not know which patients will appear in the overdiagnosed group and prefer to treat everyone. This approach increases healthcare/patient costs and the patient may be harmed due to unnecessary treatment [10]. For example, due to screening, the salvation of 1 person from prostate cancer is accompanied by the development of impotence and urinary incontinence in 47 other men without convincing justification [2].

Prostate cancer is the only example of a malignant tumor in which it is considered acceptable to regard the possibility of expectant therapy.

Cancer is a malignant disease, the natural course of which is fatal. This statement was true at the time when the diagnosis of "cancer" was made to patients who went to the doctor with severe symptoms of the disease. However, some tumors grow very quickly, others slowly, some of them stop growing completely, and some even regress. Some tumors outgrow the capacity of their blood supply (experience hypoxia), others can be recognized by the host immune system or other defense mechanisms that successfully inhibit tumor growth or lead to a decrease in its aggressiveness. The current paradigm "any cancer must be treated" leads to the abuse of anticancer therapy [2].

One of the possible mechanisms. The life expectancy of a cancer patient is ultimately determined by the actual growth rate of a neoplasm, since the death occurs when the tumor reaches a "critical" volume incompatible with life. The actual rate of tumor growth, in its turn, depends on the cell cycle duration, proliferation activity and the cell loss level. The most commonly used characteristic of a neoplasm growth rate is its volume doubling time.

According to a study (63 patients with morphologically confirmed diagnosis of prostate cancer) [4], the average level of cell loss in a tumor that has not yet been treated is about $97 \%$. In other words, 97 of every 100 new tumor cells die without treatment. Moreover, even small fluctuations of this factor lead to a principal change in the course of the disease and its outcome. So, if the level of cell losses is $94-95 \%$, then a rapidly progressing disease is observed, where doctors can rarely help with anything. If cell losses exceed $100 \%$, then the tumor will dissolve by itself. If the ratio of proliferation and cell losses is close to equilibrium, then it is assumed that in order to prolong the life of patients, in addition to traditional treatment, it is necessary to maintain a balance between proliferation and cell losses throughout the whole life. Moreover, absolutely all factors and most of all the psycho-emotional state impact on this balance.

Conflict of interest information. The author declares no conflict of interest related to the publication of this article 


\section{Literature}

1. Жуков Н. В. Фундаментальные и клинические исследования в онкологии. Существуют ли предпосылки для прорыва? / Н. В. Жуков, С. А. Румянцев, С. А. Лукьянов // Онкогематология. - 2014. - №4. - С. 54-64.

2. Назаренко Г. И. Современная ранняя диагностика рака предстательной железы - благо или профессиональное “минное поле"? Или как диагностика клинически незначимого рака может испортить больному жизнь / Г. И. Назаренко, Е. Б. Клейменова // Ультразвук. и функц. диагностика. - 2012. - № 5. - С. 95-112.

3. Петров Н. Н. Общее учение об опухолях в кратком изложении / Н. Н. Петров. - М.-Л,: Гос. изд-во, 1926. - 238 с.

4. Скорость роста и клеточные потери рака предстательной железы / Г. М. Жаринов, И. В. Чепурная, К .М. Пожарисский [и др.] // Эксп. и клин. урология. - 2016. - № 3. - С. 36-39.

5. Galmarini C. M. Survivorship in untreated breast cancer patients / C. M. Galmarini, O. Tredan, F. C. Galmarini // Med. Oncol. - 2014. - Vol. 32 . P. 29. https://doi.org/10.1007/s12032-014-0466-x.

6. Giannini E. G. Italian Liver Cancer (ITA. LI.CA) group. Prognosis of untreated hepatocellular carcinoma / E. G. Giannini, F. Farinati, F. Ciccarese // Hepatology. - 2015. - Vol. 61. - P. 184-190. https://doi.org/10.1002/hep.27443. Epub 2014 Nov 26. PMID: 25234419.

7. Hughley B. B. Survival outcomes in elderly patients with untreated upper aerodigestive tract cancer / B. B. Hughley, S. M. Sperry // Head Neck. - 2017. - Vol. 39(2). - P. 215-218. Epub 2016 Aug 10. PMID: 27507712; PMCID: PMC5844569. https://doi.org/10.1002/hed.24565.

8. Jang T. L. Low risk prostate cancer in men under age 65: the case for definitive treatment $/ \mathrm{T}$. L. Jang, F. J. Bianco, P. T. Scardino // Urol Oncol. 2007. - Vol. 25(6). - P. 510-514. PMID: 18047962; PMCID: PMC2748722. https://doi.org/10.1016/j. urolonc.2007.05.025.

9. Johnstone P. A. Survival of patients with untreated breast cancer / P. A. Johnstone, M. S. Norton // Journal of Surgical Oncology. - 2000. - Vol. 73(4). - P. 273-277. https://doi.org/10.1002/(sici)10969098(200004)73:4<273::aid-jso15>3.0.co;2-h.

10. Klotz L. Cancer overdiagnosis and overtreatment / L. Klotz // Current Opinion in Urology. - 2012. - Vol. 22(3). - P. 203-209. https://doi. org/10.1097/mou.0b013e32835259aa.
11. Kono M. Somatic mutations, clinicopathologic characteristics, and survival in patients with untreated breast cancer with bone-only and non-bone sites of first metastasis / M. Kono, T. Fujii, N. Matsuda // J Cancer. - 2018. - Vol. 9(19). - P. 3640-3646. https://doi.org/10.7150/ jca. 26825 .

12. Lazarus-Barlow W. S. The natural duration of cancer / W. S. Lazarus-Barlow, J. H. Leeming // BMJ. - 1924. - P. 2266-2267.

13. Mooi W. J. Oncogene_induced cell senescence-halting on the road to cancer / W. J. Mooi, D. S. Peeper // N. Engl. J. Med. - 2006. - Vol. 355 (10). - P. 1037-1046. https://doi.org/10.1056/ NEJMra062285

14. Pestana C. The natural history of carcinoma of the colon and rectum / C. Pestana, R. J. Reitemeier // The American Journal of Surgery. 1964. - Vol. 108, Issue 6. - P. 826-829. https://doi. org/10.1016/0002-9610(64)90041-8

15. Serrano M. Cancer regression by senescence / M. Serrano // N. Engl. J. Med. - 2007. - Vol. 356 (19). - P. 1996-1997. https://doi.org/10.1056/ NEJMcibr071461.

16. Steckler R. M. Prolonged survival in untreated breast cancer / R. M. Steckler, R. G. Martin // Am. J Surg. 1973 Jul;126(1):111-113. https:// doi.org/10.1016/s0002-9610(73)80107-2. PMID: 4714767.

17. Verkooijen H. M. Patients' refusal of surgery strongly impairs breast cancer survival / H. M. Verkooijen, G. M. Fioretta // Ann Surg. 2005. - Vol. 242(2). - P. 276-280. https://doi. org/10.1097/01.sla.0000171305.31703.84. PMID: 16041219; PMCID: PMC1357734.

18. Welch H. G. Overdiagnosis in cancer / H. G. Welch, W. C. Black // J. Natl. Cancer Inst. - 2010. - Vol. 102. - P. 605-613.

\section{ESCHATOLOGY IN ONCOLOGY: LIFE EXPECTANCY OF UNTREATED PATIENTS WITH MALIGNANT TUMORS}

\section{N.N. Kolotilov}

The purpose of the article is to remind about the problem of studying the natural life expectancy of patients with untreated cancer.

Knowledge of the clinical prognosis of untreated cancer of any localization is useful in patients with advanced disease or in an underdeveloped 
healthcare system. Historical data on untreated breast cancer patients in some cases demonstrate the possibility of long-term survival. Some cancers are invariably fatal, others are latent and do not affect the patient's life expectancy.

For the first time, the research results of the English professor, oncologist and radiologist U.S. Lazarus-Barlow (1865-1950) about natural life expectancy of 2556 untreated patients with cancerous tumors of 29 localizations based on the materials of the 1924 article, were introduced in domestic oncology.

The results of a study of the natural life expectancy of patients with untreated breast cancer, hepatocellular carcinoma, adenocarcinoma of the colon and prostate for the period 1964-2018 are presented.

The problem of overdiagnosis is considered. This term is used to refer to a side effect of technological progress. Medical imaging technology can detect cancers which have no clinical manifestations and are not fetal. The concept of «non-progressive» tumors (histologically verified tumors that do not grow or even regress) have something in common with overdiagnosis. Biological mechanisms for arresting the progression of cancer are mentioned.

Key words: life expectancy, untreated patients, overdiagnosis, breast cancer, prostate cancer.

\section{ЕСХАТОЛОГІЯ В ОНКОЛОГІЇ: ТРИВАЛІСТЬ ЖИТТЯ НЕЛІКОВАНИХ ХВОРИХ ІЗ ЗЛОЯКІСНИМИ ПУХЛИНАМИ}

\section{М.М. Колотілов}

Мета статті - нагадати про проблему вивчення природної тривалості життя хворих 3 нелікованим раком.

Вперше в вітчизняну онкологію за матеріалами статті 1924 р. введені результати досліджень англійського професора, онколога і радіолога У.С. Лазарус-Барлоу (1865-1950) природної тривалості життя 2556 нелікованих хворих при ракових пухлинах 29 локалізацій.

Представлені результати дослідження природної тривалості життя хворих 3 нелікованим раком молочної залози, гепатоцелюлярної карциноми, аденокарциноми товстої кишки і передміхурової залози за період 1964-2018 pр.
Розглянуто проблему гіпердіагностики. Цей термін використовується для позначення побічного ефекту технічного прогресу. Технології медичної візуалізації дозволяють виявляти раки, які не мають клінічних проявів і не ведуть до летального результату. 3 гіпердіагностикою перегукується поняття «непрогресующих» пухлин (гістологічно верифіковані пухлини, які не ростуть або навіть регресують). Згадано біологічні механізми зупинки прогресування раку.

Ключові слова: тривалість життя, неліковані хворі, гіпердіагностика, рак молочної залози, рак передміхурової залози.

\section{ЭСХАТОЛОГИЯ В ОНКОЛОГИИ: ПРОДОЛЖИТЕЛЬНОСТЬ ЖИЗНИ НЕЛЕЧЕННЫХ БОЛЬНЫХ СО ЗЛОКАЧЕСТВЕННЫМИ ОПУХОЛЯМИ}

\section{Н.Н. Колотилов}

Цель статьи - напомнить о проблеме изучения естественной продолжительности жизни больных с нелеченным раком.

Впервые в отечественную онкологию по материалам статьи 1924 г. введены результаты исследований английского профессора, онколога и радиолога У.С. Лазарус-Барлоу (1865-1950) естественной продолжительности жизни 2556 нелеченных больных при раковых опухолях 29 локализаций. Представлены результаты исследования естественной продолжительности жизни больных с нелеченным раком молочной железы, гепатоцеллюлярной карциномы, аденокарциномы толстой кишки и предстательной железы за период 1964-2018 гг.

Рассмотрена проблема гипердиагностики. Этот термин используется для обозначения побочного эффекта технического прогресса. Технологии медицинской визуализации позволяют выявлять раки, которые не имеют клинических проявлений и не ведут к летальному исходу. С гипердиагностикой перекликается понятие «непрогрессирующих» опухолей (гистологически верифицированные опухоли, которые не растут или даже регрессируют). Упомянуты биологические механизмы остановки прогрессирования рака.

Ключевые слова: продолжительность жизни, нелеченные больные, гипердиагностика, рак молочной железы, рак предстательной железы. 